\title{
Desulfovibrio alaskensis sp. nov., a sulphate- reducing bacterium from a soured oil reservoir
}

Correspondence

Iwona B. Beech

Iwona.Beech@port.ac.uk

\author{
Maria J. Feio, ${ }^{1} \dagger$ Vitaly Zinkevich, ${ }^{1}$ Imona B. Beech, ${ }^{1}$ Enric Llobet-Brossa, ${ }^{2}$ \\ Peter Eaton, ${ }^{1} \ddagger$ Jürgen Schmitt ${ }^{3}$ and Jean Guezennec ${ }^{4}$
}

${ }^{1}$ School of Pharmacy and Biomedical Sciences, University of Portsmouth, St Michael's Building, White Swan Rd, Portsmouth PO1 2DT, UK

${ }^{2}$ Max-Planck-Institut für marine Mikrobiologie, Celsiusstr. 1, D-28359 Bremen, Germany

${ }^{3}$ IWW, Rheinisch-Westfälisches Institut für Wasserchemie und Wassertechnologie, Moritzstr. 26, 45476 Mülheim/Ruhr, Germany

${ }^{4}$ IFREMER, Centre de Brest, DRV/VP/BMH, BP 70, 29280 Plouzané, France

A novel sulphate-reducing bacterium $\left(\mathrm{Al} 1^{\top}\right)$ was recovered from a soured oil well in Purdu Bay, Alaska. Light and atomic force microscopy observations revealed that cells were Gram-negative, vibrio-shaped and motile by means of a single polar flagellum. The carbon and energy sources used by the isolate and the salinity, temperature and $\mathrm{pH}$ ranges facilitating its growth proved to be typical of a partial lactate-oxidizing, moderately halophilic, mesophilic, sulphate-reducing bacterium. Analysis of the fatty acid profile revealed that $\mathrm{C}_{18: 0}$, iso $\mathrm{C}_{15: 0}$ and iso $\mathrm{C}_{17: 1} \omega 7 \mathrm{c}$ were the predominant species. Fatty acid profile and complete $16 \mathrm{~S}$ rRNA gene sequencing demonstrated the similarity between strain $\mathrm{Al}^{\top}{ }^{\top}$ and members of the genus Desulfovibrio. The position of strain $\mathrm{Al} 1^{\top}$ within the phylogenetic tree indicated that it clustered closely with Desulfovibrio vietnamensis DSM $10520^{\top}$ (98.9 \% sequence similarity), a strain recovered from a similar habitat. However, whole-cell protein profiles, Fourier-transform infrared studies and DNA-DNA hybridization demonstrated that, in spite of the high level of $16 \mathrm{~S}$ rRNA gene sequence similarity, there is sufficient dissimilarity at the DNA sequence level between $D$. vietnamensis DSM $10520^{\top}$ and strain $\mathrm{Al}^{\top}{ }^{\top}\left(10 \cdot 2 \%\right.$ similarity) to propose that strain $\mathrm{Al} 1^{\top}$ belongs to a separate species within the genus Desulfovibrio. Based on the results obtained, the name Desulfovibrio alaskensis sp. nov. is therefore proposed, with $\mathrm{Al}^{\top}\left(=\mathrm{NCIMB} 13491^{\top}=\mathrm{DSM} 16109^{\top}\right)$ as the type strain.
In offshore oil recovery processes, reservoir pressure is often maintained by the injection of a large volume of filtered sea water into the well. Indigenous bacteria from oil-bearing

Published online ahead of print on 26 March 2004 as DOI 10.1099/ ijs.0.63118-0.

tPresent address: IBVF - Instituto de Bioquímica Vegetal y Fotosíntesis, Centro de Investigaciones Científicas Isla de la Cartuja, Av. Américo Vespucio 49, 41092 Sevilla, Spain.

‡Present address: $\| \mathrm{Q}$ - Instituto de Investigaciones Químicas, Centro de Investigaciones Científicas Isla de la Cartuja, Av. Américo Vespucio 49, 41092 Sevilla, Spain.

Abbreviations: AFM, atomic force microscopy; FT-IR spectroscopy, Fourier-transform infrared spectroscopy; SRB, sulphate-reducing bacterium.

The GenBank/EMBL/DDBJ accession number for the 16S rRNA gene sequence of strain $A l 1^{\top}$ is $\mathrm{Y} 11984$.

The fatty acid profile and an AFM image of strain Al1 ${ }^{\top}$, FT-IR spectra of various SRB and a dendrogram based on these spectra are available as supplementary material in IJSEM Online. strata can therefore be introduced into the well. A sulphatereducing bacterium (SRB) strain, previously referred to as Al1 (Beech \& Cheung, 1995; Beech et al., 1994; Zinkevich et al., 1996), was isolated from material collected by E. van der Vende from a soured oil reservoir in Alaska (March 1991), a habitat with direct links to the marine environment, as the sea water from Purdu Bay was used in a secondary oil recovery system.

SRB enrichment was carried out using lactate as carbon source in marine Postgate medium B (Postgate, 1984) and purification was completed on semi-solid marine Postgate medium E (Postgate, 1984) as described elsewhere (Zinkevich et al., 1996). Cultures were maintained anaerobically at $37^{\circ} \mathrm{C}$ as stationary batch cultures in marine Postgate medium C (Postgate, 1984).

Light microscopy and atomic force microscopy (AFM) were used to study cell morphology. A Leitz light microscope (Laborlux S) was used to determine the Gram reaction (Gregersen, 1978), as well as cell shape and motility. 
AFM imaging was conducted in a Discoverer TMX2000 SPM (Veeco Metrology Group) as described by Feio et al. (1998) and a micrograph is available as Supplementary Fig. A in IJSEM Online. The physiological characterization of isolate $\mathrm{All}^{\mathrm{T}}$ included determination of the temperature, $\mathrm{pH}$ and salinity ranges that allowed bacterial growth. These parameters were evaluated by growing cells in marine Postgate medium B for a period of 28 days under a range of conditions. The ability of cells to use different carbon and energy sources and electron donors was also tested. Results of the morphological and physiological characterization are given in Table 1 and summarized in the species description.

Lipid extraction, esterification, fatty acid purification and quantification using GC were performed as described previously (Bligh \& Dyer, 1959). Lipids from lyophilized cells (50-100 mg) were extracted following a modified BlighDyer method (White et al., 1979). The extracted lipids were fractionated into neutral lipids, glycolipids and polar lipids by silicic acid column chromatography using appropriate volumes of chloroform, acetone and methanol, respectively. Phospholipids were subjected to mild alkaline methanolysis and the resulting fatty acid methyl esters were purified by TLC, GC and GC-MS (Guezennec, 1991). The position and geometry of the double bond of each monounsaturated fatty acid were determined using dimethyl disulphide derivatives according to a procedure described previously (Nichols et al., 1986; Guezennec, 1991). The fatty acid profile of strain $\mathrm{All}^{\mathrm{T}}$ (Supplementary Table A) revealed considerable amounts of monounsaturated fatty acids $(21 \cdot 2 \%$ total fatty acids), of which $10 \cdot 4 \%$ were isoC $\mathrm{C}_{17: 1} \omega 7 c$, a specific biomarker for the genus Desulfovibrio (Vainshtein et al., 1992).

SRB chromosomal DNA was obtained using the guanidine isothiocyanate method (Zinkevich \& Beech, 2000) from cultures grown for 7 days at $37^{\circ} \mathrm{C}$ in $10 \mathrm{ml}$ marine Postgate medium B. 16S rRNA genes of purified genomic DNA were amplified by PCR using eubacterial universal primers (Lane, 1991). Appropriate PCR products were purified using the QIAquick PCR purification kit (Qiagen) and cloned according to standard methods (Sambrook et al., 1989) in pGEM-T Easy vector (Promega). Restriction enzymes used were obtained from New England Biolabs. Escherichia coli JM 109 (Promega; Messing et al., 1981) was

Table 1. Comparison of the morphological and physiological properties of strain $\mathrm{Al} 1^{\top}$ and Desulfovibrio vietnamensis $\mathrm{DSM}$ $10520^{\top}$

Optimum values are shown in parentheses. -, No growth; +, good growth; $(+)$, weak growth; ND, not determined. Cells of both strains are vibrio-shaped with single polar flagella. Cultures did not show any growth in the absence of carbon sources and neither strain required vitamin supplements for growth. Both strains were able to utilize lactate and pyruvate and neither of them was able to utilize benzoate, butyrate, propionate $(10 \mathrm{mM})$, acetate or butanol as electron donors. Both strains produced desulfoviridin and utilized sulphate, sulphite and thiosulphate as electron acceptors with lactate as an energy and carbon source. Neither was able to utilize nitrate. Data for D. vietnamensis were taken from Nga et al. (1996).

\begin{tabular}{|c|c|c|}
\hline Characteristic & $\mathrm{Al1}^{\mathrm{T}}$ & D. vietnamensis DSM $10520^{\mathrm{T}}$ \\
\hline Temperature range $\left({ }^{\circ} \mathrm{C}\right)$ & $10-45(37)$ & $12-45(37)$ \\
\hline $\mathrm{pH}$ range & $6 \cdot 5-8 \cdot 5(7 \cdot 0)$ & $5 \cdot 0-10 \cdot 0(7 \cdot 5)$ \\
\hline $\mathrm{G}+\mathrm{C}$ content $(\mathrm{mol} \%)$ & $64 \cdot 1$ & $60 \cdot 6$ \\
\hline \multicolumn{3}{|c|}{ Utilization of electron donors in the presence of $15 \mathrm{mM}$ sulphate: ${ }^{*}$} \\
\hline Palmitate $(10 \mathrm{mM})$ & - & ND \\
\hline Glutamate & - & ND \\
\hline Glycerol (10 mM) & - & + \\
\hline Ethanol & - & + \\
\hline Fumarate & $\mathrm{ND}$ & + \\
\hline Formate & $\mathrm{ND}$ & + \\
\hline Butanol & $(+)$ & - \\
\hline Growth rate $\left(\mu_{\max }, \mathrm{h}^{-1}\right) \ddagger$ & $0 \cdot 133$ & ND \\
\hline
\end{tabular}

${ }^{\star}$ Unless otherwise stated, electron donors were tested at a concentration of $30 \mathrm{mM}$. In the tests carried out by Nga et al. (1996), 10 mM was used. $\dagger$ Blackening of the medium in three successive subcultures was considered a positive result.

¥Determined in Postgate medium $\mathrm{C}$ at $37^{\circ} \mathrm{C}$. 
used as a host strain for molecular cloning. E. coli JM 109 was grown in LB medium (Sambrook et al., 1989) and SOC medium (Promega) at $37^{\circ} \mathrm{C}$. The solid LB medium was supplemented with $100 \mu \mathrm{g}$ ampicillin $\mathrm{ml}^{-1}, 100 \mu \mathrm{g}$ X-Gal $\mathrm{ml}^{-1}$ and $0.5 \mathrm{mM}$ IPTG. Recombinant plasmid DNA was purified using a Qiagen plasmid mini kit. Both strands of the purified plasmid DNA (after restriction analysis) were sequenced by Cambridge BioSciences, Cambridge, UK.

The 16S rRNA gene sequence from $\mathrm{All}^{\mathrm{T}}$ was added to an alignment of about 15000 homologous bacterial 16S rRNA gene sequences using the alignment tool of the ARB program package (Strunk et al., 1999). Phylogenetic trees were constructed using subsets of data that included representative sequences of members of the $\delta$-Proteobacteria. Only sequences with at least $1300 \mathrm{nt}$ were used. Distance matrix and maximum-likelihood methods, as implemented in the programs PHYLIP (Felsenstein, 1993), ARB and FASTDNAML (Maidak et al., 2000), were used.

The comparison between the 16S rRNA gene sequences of $\mathrm{All}^{\mathrm{T}}$ and some SRB strains of the genus Desulfovibrio revealed sequence similarities above $86 \%$ with the majority of the species used. However, the closest relatives to strain $\mathrm{All}^{\mathrm{T}}$ were Desulfovibrio acrylicus DSM $10141^{\mathrm{T}}(89 \cdot 0 \%)$, Desulfovibrio vulgaris subsp. vulgaris Hildenborough ATCC $29579^{\mathrm{T}}(89 \cdot 4 \%)$ and Desulfovibrio vietnamensis DSM $10520^{\mathrm{T}}(98 \cdot 9 \%)$. This latter strain was recovered from the water phase of a crude oil storage tank of an offshore oil platform in Vietnam (Nga et al., 1996). The constructed phylogenetic trees were in good agreement with previously published ones (Devereux et al., 1990; Feio et al., 1998, 2000). $\mathrm{All}^{\mathrm{T}}$ and Desulfovibrio vietnamensis DSM $10520^{\mathrm{T}}$ formed a group in a lineage with an origin very close to the base of the family 'Desulfovibrionaceae' (Fig. 1). A 16S rRNA gene sequence similarity of $97 \%$ is commonly considered as the upper limit for the definition of separate species (Stackebrandt \& Goebel, 1994). Although more than $97 \%$ similarity indicates that strains may belong to the same species, it is now generally acknowledged that this rule does not always apply. DNA-DNA analysis was therefore performed to determine whether or not Desulfovibrio vietnamensis DSM $10520^{\mathrm{T}}$ and $\mathrm{Al}^{\mathrm{T}}$ were sufficiently dissimilar for the latter to be considered to belong to a novel species.

Spectroscopic DNA-DNA hybridization of Desulfovibrio vietnamensis DSM $10520^{\mathrm{T}}$ and strain $\mathrm{All}^{\mathrm{T}}$ was undertaken by DSMZ (Braunschweig, Germany). DNA was isolated from bacterial cells by chromatography on hydroxyapatite according to the procedure of Cashion et al. (1977). DNADNA hybridization was carried out as described by De Ley et al. (1970), with modifications reported by Huß et al. (1983) and Escara \& Hutton (1980), using a model 2600 spectrophotometer equipped with a model 2527-R thermoprogrammer and plotter (Gilford Instrument Laboratories). Renaturation rates were computed with the program TRANSFER.BAS (Jahnke, 1992). In spite of the high similarity between strain $\mathrm{All}^{\mathrm{T}}$ and Desulfovibrio vietnamensis DSM

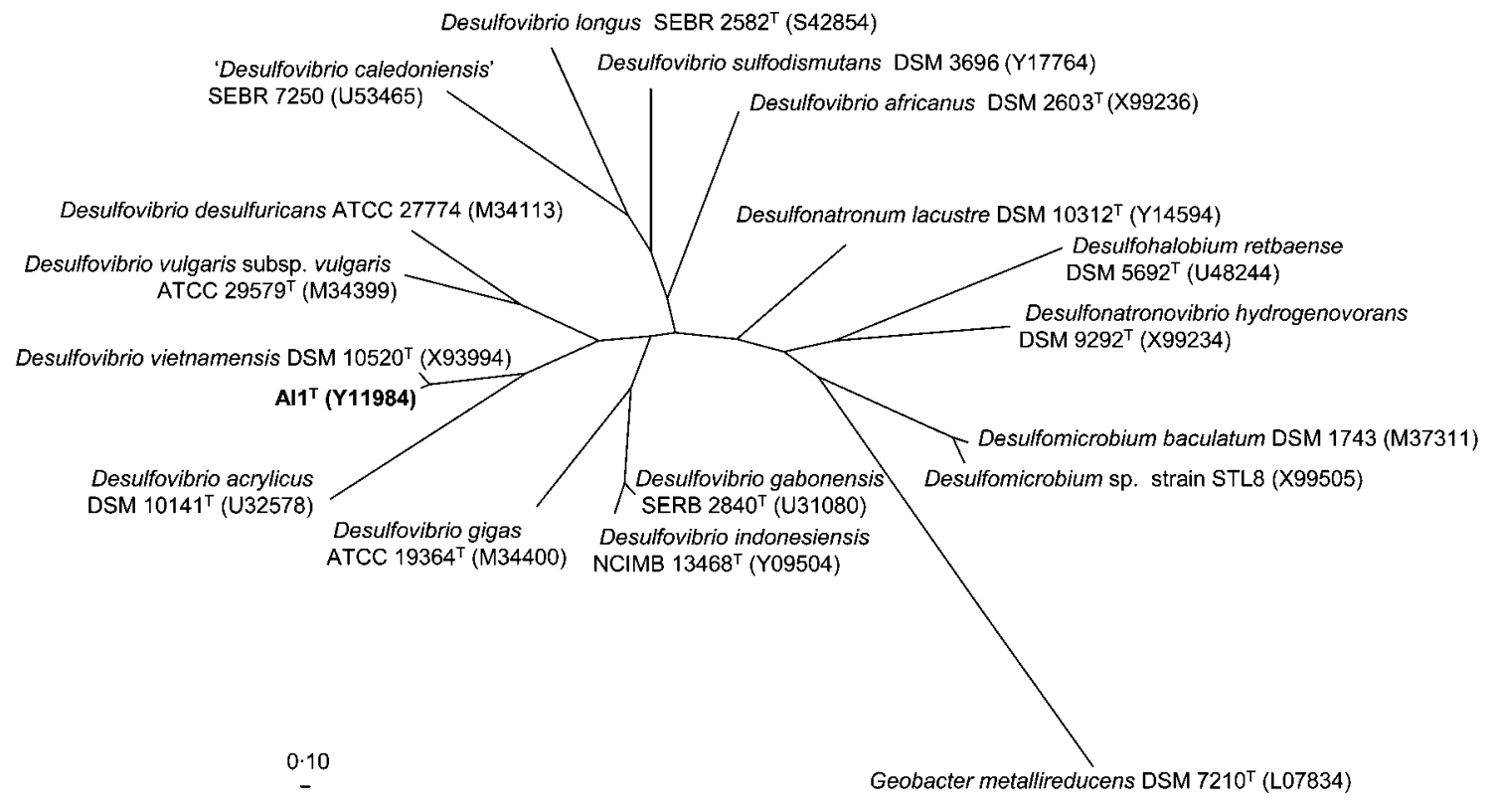

Fig. 1. Reconstructed phylogenetic tree based on $16 \mathrm{~S}$ rRNA gene sequence relationships of strain $\mathrm{A} 11^{\top}$ and a selection of species from the $\delta$-Proteobacteria. The tree is based on results of distance matrix analysis including complete or almost complete 16S rRNA gene sequences from representative bacteria of this subclass. The topology of the tree was corrected according to distance-matrix, maximum-parsimony and maximum-likelihood analyses of various datasets. Topologies that could not be resolved unambiguously are shown as multifurcation branching patterns, as previously recommended (Ludwig et al., 1998). Accession numbers are given in parentheses. 
$10520^{\mathrm{T}}$ observed at the $16 \mathrm{~S}$ rRNA level, DNA-DNA hybridization revealed only $10 \cdot 2 \%$ relatedness. This result confirmed that the two strains are not related at the species level when the threshold value of $70 \%$ for the definition of species is considered (Wayne et al., 1987). Furthermore, the observed difference in melting temperatures between the DNA of the two strains $\left(11^{\circ} \mathrm{C}\right)$ indicates considerable difference in their DNA base composition, further confirming that strain $\mathrm{All}^{\mathrm{T}}$ belongs to a novel species.

To further distinguish Desulfovibrio vietnamensis DSM $10520^{\mathrm{T}}$ and $\mathrm{Al}^{\mathrm{T}}$ at the phenotypic level, whole-cell protein profiles and Fourier-transform infrared (FT-IR) spectroscopy analysis were performed. SDS-PAGE of whole-cell proteins is a rapid method for distinguishing bacterial species and has a similar level of discrimination to DNADNA hybridization (Jackman, 1987). Although there is not a genus-specific pattern (Jackman, 1987), differences in the protein patterns of whole cells reflect differences in the genomic content of the organism. Therefore, bacterial cells that are grown and recovered in an identical manner generate reproducible protein patterns, which can be used as fingerprints for their identification.

Whole-cell protein profile comparisons between Desulfovibrio vietnamensis DSM $10520^{\mathrm{T}}$ and strain $\mathrm{All}^{\mathrm{T}}$ were carried out with cultures grown under identical conditions in marine Postgate medium $\mathrm{C}$ for 5 days. Cells were harvested from $10 \mathrm{l}$ batch cultures by centrifugation at $3000 \mathrm{~g}$ for $30 \mathrm{~min}$. The pelleted cells were washed in $30 \mathrm{ml}$ cold $50 \mathrm{mM}$ MOPS buffer (pH 7·4) with $0 \cdot 15 \mathrm{M} \mathrm{NaCl}$ and the pellet, after subsequent centrifugation at $3000 \mathrm{~g}$ for $30 \mathrm{~min}$, was resuspended in $30 \mathrm{ml}$ MOPS buffer. The cell preparation was then sonicated in a Soniprep 150 sonicator for $10 \times 1 \mathrm{~min}$ bursts at $16 \mu \mathrm{m}$ amplitude with $30 \mathrm{~s}$ intervals. Any unbroken cells and remaining culture debris were then removed by centrifugation at $3500 \mathrm{~g}$ for $30 \mathrm{~min}$ and the supernatant was stored at $-20^{\circ} \mathrm{C}$ for whole-cell protein profile analysis. Protein profile analysis was performed by SDS-PAGE in $12.5 \% \mathrm{~T}$ acrylamide gels according to the method of Laemmli (1970). Gels were stained with Coomassie brilliant blue R-250 (Sigma). The protein profiles obtained for the whole cells of $\mathrm{All}^{\mathrm{T}}$ and Desulfovibrio vietnamensis DSM $10520^{\mathrm{T}}$ (Fig. 2) clearly demonstrated dissimilarities, thus supporting the evidence that strain $\mathrm{Al} 1^{\mathrm{T}}$ belongs to a novel species.

FT-IR spectroscopy provides chemical information about the biomolecular composition of whole bacterial cells. This technique is suitable for bacterial characterization due to the high specificity of obtained spectra (Schmitt et al., 1995; Schmitt \& Flemming, 1998). It can also be used to discern different bacterial species or even strains, providing cultures are grown under identical conditions. Hence, three independent replicate cultures of the SRB species investigated were grown anaerobically in $10 \mathrm{ml}$ vials in Postgate medium $\mathrm{C}$ at $37^{\circ} \mathrm{C}$. Cells were harvested after 2 days incubation by centrifugation at $5000 \mathrm{~g}$. Pelleted cells were freeze-dried after washing with $0 \cdot 9 \%(\mathrm{w} / \mathrm{v}) \mathrm{NaCl}$ solution.

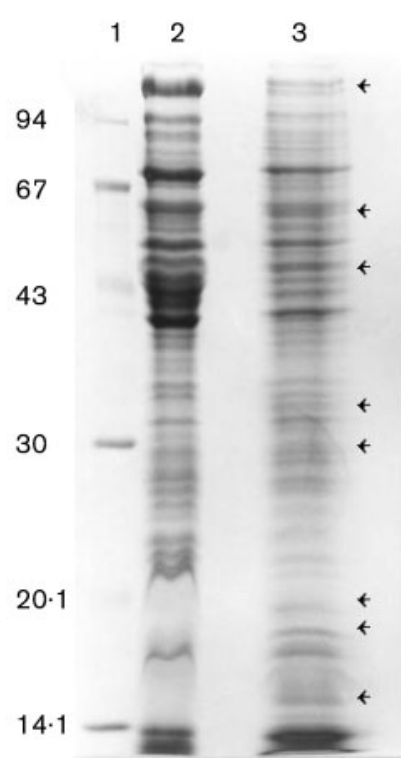

Fig. 2. Electrophoretogram showing whole-cell protein profiles of $\mathrm{Al}^{\top}$ (lane 2) and D. vietnamensis DSM 10520 (lane 3); low molecular range protein markers (Pharmacia) are in lane 1. Loaded samples contained $100 \mu \mathrm{g}$ protein per lane. Arrows indicate the positions of the protein bands with more significant differences.

Control replicates of sterile media were also lyophilized and analysed. Spectra were collected using a Mattson RS/2 research series spectrometer (ThermoUnicam) and data were manipulated using WINFIRST software. All spectra were acquired in transmission mode, by the $\mathrm{KBr}$ disc method. In each case, cells $(2 \mathrm{mg}$ ) were diluted in $200 \mathrm{mg} \mathrm{KBr}$ powder to achieve a $1 \%(\mathrm{w} / \mathrm{w})$ concentration before pressing the disc. After a spectral quality check, data treatment consisted of vector-normalization of the spectra derivatives for statistical evaluation and construction of dendrograms.

The FT-IR spectra of $\mathrm{All}^{\mathrm{T}}$, Desulfovibrio vietnamensis DSM $10520^{\mathrm{T}}$, Desulfovibrio indonesiensis NCIMB $13468^{\mathrm{T}}$, Desulfovibrio gabonensis DSM $10636^{\mathrm{T}}$, Desulfovibrio gigas ATCC $19364^{\mathrm{T}}$, Desulfovibrio desulfuricans ATCC 27774, Desulfovibrio vulgaris subs. vulgaris strain Hildenborough ATCC $29579^{\mathrm{T}}$ and Desulfovibrio vulgaris strain Woolwich NCIMB 8457 revealed considerable differences, mainly in the region between 1200 and $900 \mathrm{~cm}^{-1}$ (Supplementary Fig. B). This region is characterized by the presence of strain-specific bands that derive predominantly from the $-\mathrm{C}-\mathrm{O},-\mathrm{C}-\mathrm{OH}$, $-\mathrm{C}-\mathrm{O}-\mathrm{C}$ and $-\mathrm{C}-\mathrm{O}-\mathrm{P}$ stretching vibrations. Statistical cluster analysis of the obtained FT-IR spectra, based on the bands at $1311 \mathrm{~cm}^{-1}$, the phosphate groups with a maximum at $1234 \mathrm{~cm}^{-1}$ and the $-\mathrm{C}-\mathrm{O},-\mathrm{C}-\mathrm{O}-\mathrm{C}$ and $-\mathrm{C}-\mathrm{O}-\mathrm{H}$ stretching region with bands at $1160 \mathrm{~cm}^{-1}, 1083 \mathrm{~cm}^{-1}$ and $969 \mathrm{~cm}^{-1}$, led to the construction of a dendrogram (Supplementary Fig. C). Despite the fact that the dendrogram reflects whole cell composition, it shows a remarkable agreement with phylogenetic trees constructed based on full 16S rRNA 
gene sequences. This analysis confirmed the high degree of similarity between strain $\mathrm{All}^{\mathrm{T}}$ and Desulfovibrio vietnamensis DSM $10520^{\mathrm{T}}$ but clearly established that they are separate species.

Desulfovibrio gigas ATCC $19364^{\mathrm{T}}$, Desulfovibrio gabonensis DSM $10636^{\mathrm{T}}$ and Desulfovibrio indonesiensis NCIMB $13468^{\mathrm{T}}$ formed a separate group in FT-IR analysis. This grouping was based on the similarity of these strains in the region between 1200 and $900 \mathrm{~cm}^{-1}$, with a multiple band with peaks at $1128 \mathrm{~cm}^{-1}, 1083 \mathrm{~cm}^{-1}$ and $1046 \mathrm{~cm}^{-1}$. Previous studies that did not include FT-IR analysis (Feio et al., 1998) placed these three Desulfovibrio strains in the same group, thus verifying the FT-IR data and validating the use of FT-IR spectroscopy of whole cells as a rapid and highly sensitive technique for identification and characterization of SRB.

Despite the high level of similarity found between the $16 \mathrm{~S}$ rRNA gene sequences of strain $\mathrm{All}^{\mathrm{T}}$ and Desulfovibrio vietnamensis DSM $10520^{\mathrm{T}}$ and the similarities in the environment from which the two isolates were recovered, the remaining evidence, i.e. DNA-DNA hybridization, FT-IR analysis and whole-cell protein profiles, clearly demonstrates the difference between these two strains. Our data strongly indicate that strain $\mathrm{All}^{\mathrm{T}}$ represents a novel species belonging to the genus Desulfovibrio and classification of this isolate as a representative of a novel species, Desulfovibrio alaskensis sp. nov., is therefore proposed.

\section{Description of Desulfovibrio alaskensis sp. nov.}

Desulfovibrio alaskensis (al.ask.en'sis. N.L. masc. adj. alaskensis from Alaska, referring to the place of isolation).

Gram-negative, non-spore-forming, vibrio-shaped cells, $1 \cdot 0-5 \cdot 0 \times 0 \cdot 5-1 \cdot 2 \mu \mathrm{m}$. Cells occur singly and are motile by means of a single polar flagellum. Grows at $\mathrm{pH} 6 \cdot 5-8 \cdot 5$, $10-45^{\circ} \mathrm{C}$ and in $0-10 \%(\mathrm{w} / \mathrm{v}) \mathrm{NaCl}$. Maximum growth rate under optimal growth conditions in marine Postgate medium $\mathrm{C}\left[37^{\circ} \mathrm{C}, \mathrm{pH} 7 \cdot 0\right.$ and $\left.2 \cdot 5 \%(\mathrm{w} / \mathrm{v}) \mathrm{NaCl}\right]$ using lactate as carbon source is $0 \cdot 133 \mathrm{~h}^{-1}$. Vitamins are not required for growth. Strictly anaerobic, reduces sulphate, sulphite and thiosulphate, producing sulphide. Nitrate is not used as an electron acceptor. Substrates that are oxidized by sulphate reduction are lactate, pyruvate and succinate. Ethanol and butanol can be utilized fermentatively (for a limited number of generations). Desulfoviridintype sulphite reductase is present. DNA G $+\mathrm{C}$ content is $64 \cdot 1 \mathrm{~mol} \%$. Major cellular fatty acids are $\mathrm{C}_{18: 0}$, iso $\mathrm{C}_{15: 0}$ and iso $\mathrm{C}_{17: 1} \omega 7 \mathrm{c}$.

The type strain is $\mathrm{All}^{\mathrm{T}}\left(=\mathrm{NCIMB} 13491^{\mathrm{T}}=\mathrm{DSM} 16109^{\mathrm{T}}\right)$, isolated from the production fluids of offshore oilfields in Alaska.

\section{Acknowledgements}

The authors would like to thank PRAXIS XXI (Portugal) for financial support (grant BD/5682/95 awarded to M. J.F.), Dr J. Smith (SPM
Laboratory, University of Portsmouth) for his help with the AFM imaging and Dr J. Mitchell (School of Biological Sciences, University of Portsmouth) for the help provided in the initial stages of the $16 \mathrm{~S}$ rRNA gene sequence analysis.

\section{References}

Beech, I. B. \& Cheung, C. W. S. (1995). Interactions of exopolymers produced by sulphate-reducing bacteria with metal ions. Int Biodeterior Biodegrad 35, 59-72.

Beech, I. B., Cheung, C. W. S., Chan, C. S. P., Hill, M. A., Franco, R. \& Lino, A. R. (1994). Study of parameters implicated in the biodeterioration of mild steel in the presence of different species of sulphate-reducing bacteria. Int Biodeterior Biodegrad 34, 289-303.

Bligh, E. G. \& Dyer, W. J. (1959). A rapid method of total lipid extraction and purification. Can J Biochem Physiol 37, 911-917.

Cashion, P., Holder-Franklin, M. A., McCully, J. \& Franklin, M. (1977). A rapid method for the base ratio determination of bacterial DNA. Anal Biochem 81, 461-466.

De Ley, J., Cattoir, H. \& Reynaerts, A. (1970). The quantitative measurement of DNA hybridization from renaturation rates. Eur J Biochem 12, 133-142.

Devereux, R., He, S. H., Doyle, C. L., Orkland, S., Stahl, D. A., LeGall, J. \& Whitman, W. B. (1990). Diversity and origin of Desulfovibrio species: phylogenetic definition of a family. J Bacteriol 172, 3609-3619.

Escara, J. F. \& Hutton, J. R. (1980). Thermal stability and renaturation of DNA in dimethyl sulfoxide solutions: acceleration of the renaturation rate. Biopolymers 19, 1315-1327.

Feio, M. J., Beech, I. B., Carepo, M. \& 8 other authors (1998). Isolation and characterization of a novel sulphate-reducing bacterium of the Desulfovibrio genus. Anaerobe 4, 117-130.

Feio, M. J., Beech, I. B., Carepo, M. \& 8 other authors (2000). Desulfovibrio indonesiensis corrig. sp. nov. In Validation of the Publication of New Names and New Combinations Previously Effectively Published Outside the IJSEM, List no. 75. Int J Syst Evol Microbiol 50, 1415-1417.

Felsenstein, J. (1993). PHYLIP (phylogenetic inference package), version 3.5c. Department of Genetics, University of Washington, Seattle, WA, USA.

Gregersen, T. (1978). Rapid method for distinction of Gramnegative from Gram-positive bacteria. Eur J Appl Microbiol Biotechnol 5, 123-127.

Guezennec, J. (1991). Influence of cathodic protection of mild steel on the growth of sulphate-reducing bacteria at $35^{\circ} \mathrm{C}$ in marine sediments. Biofouling 3, 339-348.

Huß, V. A. R., Festl, H. \& Schleifer, K. H. (1983). Studies on the spectrophotometric determination of DNA hybridization from renaturation rates. Syst Appl Microbiol 4, 184-192.

Jackman, P. J. H. (1987). Microbial systematics based on electrophoretic whole-cell protein patterns. Methods Microbiol 19, 209-225. Jahnke, K. D. (1992). Basic computer program for evaluation of spectroscopic DNA renaturation data from GILFORD System 2600 spectrometer on a PC/XT/AT type personal computer. J Microbiol Methods 15, 61-73.

Laemmli, U. K. (1970). Cleavage of structural proteins during the assembly of the head of bacteriophage T4. Nature 227, 680-685.

Lane, D. J. (1991). 16S/23S rRNA sequencing. In Nucleic Acid Techniques in Bacterial Systematics, pp. 115-175. Edited by E. Stackebrandt \& M. Goodfellow. Chichester: Wiley.

Ludwig, W., Strunk, O., Klugbauer, S., Klugbauer, N., Weizenegger, M., Neumaier, J., Bachleitner, M. \& Schleifer, 
K.-H. (1998). Bacterial phylogeny based on comparative sequence analysis. Electrophoresis 19, 554-568.

Maidak, B. L., Cole, J. R., Lilburn, T. G. \& 9 other authors (2000). The RDP (Ribosomal Database Project) continues. Nucleic Acids Res 28, 173-174.

Messing, J., Crea, R. \& Seeburg, P. H. (1981). A system for shotgun DNA sequencing. Nucleic Acids Res 9, 309-321.

Nga, D. P., Ha, D. T. C., Hien, L. T. \& Stan-Lotter, H. (1996). Desulfovibrio vietnamensis sp. nov., a halophilic sulfate-reducing bacterium from Vietnamese oil fields. Anaerobe 2, 385-392.

Nichols, P. D., Guckert, J. B. \& White, D. C. (1986). Determination of monounsaturated fatty acid double-bond position and geometry for microbial monocultures and complex consortia by capillary GC-MS of their dimethyl disulphide adducts. J Microbiol Methods 5, 49-55.

Postgate, J. R. (1984). The Sulphate-reducing Bacteria. Cambridge: Cambridge University Press.

Sambrook, J., Fritsch, E. F. \& Maniatis, T. (1989). Gel electrophoresis of DNA. In Molecular Cloning: a Laboratory Manual, 2nd edn, pp. 6.3-6.8. Cold Spring Harbor, NY: Cold Spring Harbor Laboratory.

Schmitt, J. \& Flemming, H.-C. (1998). FTIR-spectroscopy in microbial and material analysis. Int Biodeterior Biodegrad 41, 1-11.

Schmitt, J., Nivens, D., White, D. C. \& Flemming, H.-C. (1995). Changes of biofilm properties in response to sorbed substances: an FTIR-ATR study. Water Sci Technol 32, 149-155.
Stackebrandt, E. \& Goebel, B. M. (1994). Taxonomic note: a place for DNA-DNA reassociation and 16S rRNA sequence analysis in the present species definition in bacteriology. Int J Syst Bacteriol 44, 846-849.

Strunk, O., Gross, O., Reichel, B. \& 11 other authors (1999). ARB: a software environment for sequence data. Department of Microbiology, Technische Universität München, Munich, Germany. http://www.arb-home.de/

Vainshtein, M., Hippe, H. \& Kroppenstedt, R. M. (1992). Cellular fatty acid composition of Desulfovibrio species and its use in classification of sulphate-reducing bacteria. Syst Appl Microbiol 15, 554-566.

Wayne, L. G., Brenner, D. J., Colwell, R. R. \& 9 other authors (1987). International Committee on Systematic Bacteriology. Report of the ad hoc committee on reconciliation of approaches to bacterial systematics. Int J Syst Bacteriol 37, 463-464.

White, D. C., Davis, W. M., Nickels, J. S., King, J. S. \& Bobbie, R. J. (1979). Determination of the sedimentary microbial biomass by extractable lipid phosphate. Oecologia 40, 51-62.

Zinkevich, V. \& Beech, I. B. (2000). Isolation of intact high molecular weight chromosomal DNA from Desulfovibrio spp. Mol Biol Today 1, 29-33.

Zinkevich, V., Bogdarina, I., Kang, H., Hill, M., Tapper, R. \& Beech, I. B. (1996). Characterisation of exopolymers produced by different isolates of marine sulphate-reducing bacteria. Int Biodeterior Biodegrad 37, 163-172. 